\title{
PATH ANALYSIS ON THE DETERMINANTS OF NEONATAL ASPHYXIA AT DR. SAIFUL ANWAR HOSPITAL, MALANG
}

\author{
Dewy Indah Lestary1), Endang Sutisna Sulaeman²), Nunuk Suryani3) \\ ${ }^{1)}$ Academy of Midwifery Wijaya Kusuma, Malang, East Java \\ 2)Faculty of Medicine, Sebelas Maret University \\ 3)Faculty of Teaching and Educational Sciences, Sebelas Maret University
}

\begin{abstract}
Background: Neonatal asphyxia is one of the main causesof neonatal mortality. Many factors may have caused neonatal mortality. This study aimed to investigate the determinants of neonatal asphyxia at Dr. Saiful Anwar Hospital, Malang.

Subjects and Method: This was an observational analytic study with case control design. The study was conducted at Dr.Saiful Anwar, Malang, East Java, in June 2016. A total of 53 newborn babies with asphyxia (cases) and 159 newborn babies without asphyxia (controls) were selected by fixed disease sampling for this study. There were three exogenous variables: prematurity, maternal age, and parity. The endogenous variables were birthweight and neonatal asphyxia. The data were collected by a checklist. The data were analyzed by path analysis model.

Results: Low birthweight had positive direct effect on the risk of neonatal asphyxia $(b=1.61 ; 95 \% \mathrm{CI}=0.86$ to $2.37 ; \mathrm{p}<0.001)$. Prematurity $(\mathrm{b}=0.93$; $95 \% \mathrm{CI}=0.13$ to $1.74 ; \mathrm{p}<0.023)$, maternal ages $<20$ or $\geq 35$ years $(\mathrm{b}=0.97$; $95 \% \mathrm{CI}=0.05$ to $1.87 ; \mathrm{p}<0.034)$, and parity primipara or $\geq 4$ parity $(\mathrm{b}=1.00$; $95 \% \mathrm{CI}=0.155$ to $1.85 ; \mathrm{p}<0.021$ ), had positive indirect effects on the risk of neonatal asphyxia via low birthweight.

Conclusion: Low birthweight had positive direct effect on the risk of neonatal asphyxia. Prematurity, maternal ages $<20$ years or $\geq 35$ years, and parity primipara or $\geq 4$ parity, had positive indirect effects on the risk of neonatal asphyxia via low birthweight.
\end{abstract}

Keywords: neonatal asphyxia, low birth weight, prematurity, maternal age, parity

Correspondence: Dewy Indah Lestary. Academy of Midwifery Wijaya Kusuma, Malang, East Java. Email: dewylestary86@gmail.com. 